\title{
Does the Pagan King Reply? Malayalam Documents on the Portuguese Arrival in India
}

\author{
MAHMOOD KOORIA* \\ Email: mahmoodpana@gmail.com; m.kooriadathodi@hum.leidenuniv.nl
}

This article is a response to Sebastian Prange's essay in Itinerario 41, no. 1 (2017): 151173 wherein he presented a 'virtually unknown manuscript' on the Portuguese arrival in India as an Indian voice, unheard in the existing historiography. Prange had consulted the English translation of a Malayalam text by John Wye, that the former had assumed to be lost. However its original palm-leaf manuscript (ōla) is kept at the British Library. This ōla, entitled Kêrala Varttamānam, brings to light some remarkable omissions and a few discrepancies in Wye's translation. Closely reading different manuscripts in Malayalam, Arabic, and English I argue that this ōla is in fact a translation of a sixteenth-century Arabic text, Tuhfat al-mujāhidīn, well known among scholars of its place and period. Taking it a step ahead, I argue that the very existence of this text points towards the cross-cultural and cross-linguistic interactions between the Arabic and Malayalam spheres of premodern Malabar. The óla demonstrates one of the first instances of Malayalam literature's engagement with a secular and historical theme as the arrival of the Portuguese. In addition, Malayalam works such as Kéralōlpatti and Kérala-palama are clear voices from Malabar on the Portuguese arrival and consequent episodes.

Keywords: South India, Malabar, Portuguese, Arabic, Malayalam, translation, literary interactions

In Itinerario 41, no. 1 (2017), Sebastian Prange introduced, edited, and transcribed a "virtually unknown manuscript on the Portuguese arrival in India" which arguably provides an Indian voice unheard in the existing historiography that is "characterized by an inherently European perspective" with explicit focus on European themes and actors. ${ }^{1}$ The manuscript in question is "Translation of a History of the Portuguese Landing in India, Written on the Leaves of the Brab Tree (Called Ola) in the Malabar Language" 
by John William Wye, an officer in the English East India Company in the late eighteenth and early nineteenth centuries. Indeed, it is a fascinating document, previously unpublished, preserved in two manuscripts at the British Library (India Office Records, MS. IO Eur. K.194 and K.195). In the introduction to the text, Prange invites attention to the importance of the manuscript by explaining how it has been continuously overlooked in the scholarship on early modern South Asia, the Indian Ocean world, and Portuguese expansion. He speculates about the original Malayalam ōla (palm-leaf) manuscript, which might have been lost along with several other manuscripts produced in the Malabar Coast in the sixteenth and seventeenth centuries.

However, the original ôla of Wye's translation has survived and is kept nowhere else but at the very same British Library. Comparing this original ōla against the English translation brings to light some remarkable omissions as well as a few discrepancies. These place Prange's arguments in a different light, while contributing to our understanding of historical literary interactions between the Malayalam and Arabic spheres of southern India in the sixteenth to eighteenth centuries.

The Malayalam ōla manuscript is titled Kéraḷ Varttamānam, neatly written in twenty-eight palm-leaf folios of $10 \times 1$ inches, inscribed on both sides with five lines on each side. It has been catalogued as Malayalam manuscript no. $11^{*}$ of the British Library and has been microfilmed as IOL, Neg. $824 .^{2}$ Its copying was finished on 25 Karkațakam 967 of Malayalam Era, which corresponds to 20 August 1792 CE. We do not know the exact date of compilation, but the events described in the text end in 763 of Kollam Era or 998 Hijri Era, which corresponds to $1588 \mathrm{CE}$, and this might indicate the potential time of its writing.

In the following, I identify the source of this text on the basis of the original ola vis-à-vis its translation by John Wye. A missing sentence in the translation informs us about its Arabic source, which I argue is the Tuhfat al-mujähidīn by Zayn al-Dīn al-Malaybārī (d. ca. 1583). In order to substantiate this, I compare and connect both texts (along with their English and Malayalam translations) and point towards a few convergences and divergences in the translation process. In the next section, I elaborate on the ways in which the original Malayalam òla itself was translated from the Arabic source, with at least two people involved. This interaction between Malayalam and Arabic literary spheres in premodern Kerala is notable, for we know of few other such exchanges between Arabic and Malayalam in the premodern context despite both languages coexisting in the same geographical, chronological, and cultural terrain. In the last section, I come back to the question of whether we have any other primary sources in Malayalam on the Portuguese arrival at the Malabar Coast. As an answer, I suggest a few titles such as Kérala-palama and Kéralōlpatti which await further scholarly research.

\section{A Hidden/Removed Source}

Based on Wye's translation, Prange endeavours to characterise the translated text as a Malayalam original in which for first time we hear the voice of the local Hindu kingdom 
of the Zamorins: "It affords, pace Camões, a distant echo of the pagan king speaking at last." ${ }^{3}$ However, what is interestingly missing in Wye's translation is a sentence that puts this claim into question. The Malayalam manuscript states that it is written on the basis of an Arabic narrative from the House of the Qādī, the Muslim judge, in Calicut. The last sentence in the manuscript reads: "Śrī gurubhyō namah subhastuh $\bar{\imath}$ varttamānam kollam 25 Karkațakam 967nu kolikkotța kātiyāruțe kissāvil ninnu parañ̃u elutippatatre," which means "Blessings and salutations to the guru, this is the good end. This account (varttamānam) has been written down on dictation from the kissa of Calicut's qāḍi on 25 Karkatakam $967 \mathrm{KE}$ " [1792 CE]. It is quite possible that there were other copies or recensions of the text that may not have contained this passage and Wye might have used one of those, but the contextual evidence and the close proximity of both this manuscript and its translation in terms of their production, chronology, and later trajectories ending up at the British Library point to the likelihood that Wye depended on this manuscript for his translation rather than another copy or recension. In any event, this very important statement on its source is one of four sentences omitted in the Wye translation. Absence of this information has led Prange to speculate on the original source, but the Malayalam text clearly indicates that its source was the kissa (transmitted orally or textually) at the Qāḍi House in Calicut. It is widely known among Malabar historians and scholars that the Qāḍi House hosts several Arabic and Arabic-Malayalam manuscripts, many of which have been handed down through generations. Only a few scholars have utilised this collection in order to unravel or survey the rich literary, linguistic, and religious traditions of Muslims in Malabar. ${ }^{4}$

The term kissa used in this sentence does not specify any particular text. It is a Malayalam word derived from the Arabic word qișsa, which means story, narrative, account, or tale. In the Malabar Coast, the term qișsa was used to indicate any stories related to Islamic traditions or Muslim communities. The most renowned, and possibly the oldest, text to use the term is the Qișsat Shakarwatī Farmā d̦ (Tale of Cakravartti Perumāḷ), an Arabic text that narrates the story of a Malabar king who left his kingdom for Arabia in the early seventh century and embraced Islam at the hand of the Prophet Muhammad. ${ }^{5}$ In nineteenth-century Arabic-Malayalam literature (Malayalam written in Arabic script, similar to Jāwī for Malay, Arwī for Tamil, and Aljamiado for European languages), the term became very popular in the titles of songs and accounts of historical and ahistorical figures of Islam. The qișsa, although it primarily referred to the written texts, is not limited to textual narratives alone. Rather, it was also used for oral traditions, as we see all across the Islamic world. It was a generic term for all sorts of tales and histories in general, while tāri kh , an Arabic term for history and chronicles, was almost unused earlier in the Malabar context. ${ }^{6}$ The Kérala Varttamānam's acknowledgement of a kissa from the Qāḍi House along with a reference to the translation-cum-scribal process indicates its Arabic source preserved in the written form.

\section{Translating the Tuhfa}

Which text was the Arabic source of the Kêrala Varttamānam? With no doubt, I can say that it is the Tuhfat al-mujāhidīn fi Ba'd Akhbār al-Burtuḡāliyyīn (Gift for warriors with 
some accounts on the Portuguese) of Zayn al-Dīn al-Malaybārī. The close similarities in contents and discussions between the Kèraḷ Varttamānam in Malayalam (and the Wye translation in English) and the Tuhfat al-mujähidīn (henceforth Tuhfa) in Arabic are not accidental overlaps. Rather, the former emerges from the latter. The Malayalam is often a sentence-to-sentence translation of the Tuhfa, to an extent that a dictated translation can render it accurately. The ideas, phrases, and expressions stand in close proximity and the chronological order and narrative structure are the same. To exemplify the interconnections between the texts as translations, we can take some random sections from both texts and compare them. In an initial section on the chieftaincies and rulers in Malabar, the Tuhfa states:

There are in chieftains whose territories do not exceed one parasang, while others have powers over more extensive territories. Of these some have at their command one hundred soldiers or less, or two hundred to three hundred, thousand, five thousand, ten thousand, thirty thousand, hundred thousand and more, and so on. Some territories join in league and are governed by two or three persons together. And of them some have greater power and bigger army. Quarrels and skirmishes take place occasionally among them, but this does not affect their coalition rule.

The Kèrala Varttamānam translates the same passage:

Some of those kings had one katam of kingdom and some more. There were rulers with forces consisting of hundred, two hundred, three hundred, thousand, five thousand, ten thousand, thirty thousand, hundred thousand and even more soldiers. Some countries were ruled jointly by two kings. Some others have three or more kings. In the kingdom jointly ruled by two kings, they would not quarrel or trespass in the boundaries, even if one of the two was stronger. Even if anyone of the joint rulers was away, it did not affect their unity. ${ }^{7}$

The Wye manuscript also has the same passage, except he slightly mistranslates the last sentence as "if any did quarrel, he would get no one to assist him," for it has a very complicated sentence structure in Malayalam. ${ }^{8}$

In another description of the tussles between the Portuguese, Zamorins, and Muslims in the early sixteenth century, the Tuhfa says:

Then the accursed Portuguese began to build a solid fort while the subjects of the Zamorin set out to the Arabian ports in four ships laden with pepper and dried ginger. Like others, they too began to make trade trips as before to Gujarat and other destinations carrying passes from the Portuguese. This was in the year 920 or $921 \mathrm{HE}$. By the time the first four ships to the Arabian ports returned to Calicut, the Portuguese had completed the construction of their fort in Calicut. Then they forbade Muslims from making further trips to the Arabian ports with pepper and ginger in their ships. Thus, they wanted to monopolise the trade in pepper and dried ginger. Whenever they saw even a small quantity of these two spices in any ship, they seized the ship, its contents and its crew.

The Kérala Varttamānam translates the same passage:

When the Portuguese began to construct the fort, the Mappilas began sailing to the Arabian coast in four ships laden with dried ginger and pepper. They took the pass and flag of the Portuguese. That was in $921 \mathrm{AH} / 689 \mathrm{KE}$. The ships bound for Mecca 
disposed of their cargo and returned to Calicut, while the Portuguese finished the construction of the fort. After this, the Portuguese declared that they would not permit the export of dried ginger and pepper to Mecca. They insisted that nobody other than themselves should involve in the trade of pepper and ginger. They started the trade themselves. They began to seize all the cargoes and the contents whenever they saw even a piece of dried ginger or grain of pepper in a ship. ${ }^{9}$

I cite these passages at length only to show how the Tuhfa has been translated in the Kérala Varttamānam. These passages represent the larger characteristics in the tone and style of the translation, fluctuating from sentence-to-sentence adaptations with similar idioms and word structures to selective additions, omissions, summarisations, and elaborations. In the following, I shall demonstrate the convergence and divergence between the original text and the translation, noting that any free translation takes some liberties for the target audience.

The first part of the Kerrala Varttamānam is a translation of Section 2 of the Tuhfa (titled "History of the Advent and Spread of Islam in Malabar"). The story of a local king's journey to Arabia and conversion to Islam (which the Tuhfa possibly took from the Qișsat Shakarwatī Farmā d mentioned above ${ }^{10}$ ) is summarised in a few lines standing within the narrative frame of the Tuhfa. From there, the Kérala Varttamānam narrates the whole remaining section with some minimal elaboration. It avoids Section 3 ("Certain Strange Customs of the Hindus in Malabar") of the Tuhfa and comes straight to Section 4 ("The Arrival of the Portuguese in Malabar and a Brief Account of their Shameful Deeds") and translates the following chapters with some liberties of selection and deletion.

In chapter 1 (all the chapters mentioned henceforward refer to the chapters of the Tuhfa; the Kérala Varttamānam does not provide chapterisation), a paragraph-length explanation in the Tuhfa on why the Zamorins of Calicut attacked the kings of Cochin in the early sixteenth century when the latter helped the Portuguese and the consequent usurpation of the throne is left out. Following the second battle with the Portuguese and Cochin, the Tuhfa's discussion on the Zamorins' draining economy due to wars, their search for support from the foreign kingdoms of Gujarat, Bijapur, and Egypt and the following battles in Diu, Aden, and Jeddah all have been left out. Instead it comes straight to the Portuguese attack on the Nākhuda Mithqāl Mosque in Calicut. It keeps all other details before and after, except for a description of a battle in Aden, which has also been omitted. This does not mean that the text is entirely parochialised by eliminating all the encounters outside Malabar, because it also discusses the Portuguese expeditions and battles in Goa in this section.

The text also tones down the Muslim/Islamic voice apparent in the Tuhfa through selective deletion of sentences. It normalises fights which are otherwise described with a religious undertone in the Tuhfa as Muslims fighting a holy war in the cause of Allah. Likewise, it also avoids intermittent prayers of the Tuhfa in support of the Muslims and Zamorins as well as curses against the Portuguese using Islamic idioms. It also does not subscribe to the religious and political overtones of the Tuhfa. When the Tuhfa says, for example, that Adil Shah defeated the Portuguese and made Goa 
once again "part of Islamic territory" (dār al-Islam), the Kèrala Varttamānam only mentions that he reconquered the land. Along these lines, it removes the entire chapter 2 ("Certain Shameful Deeds of the Portuguese") in which the Tuhfa laments about the Portuguese attacks against Muslim traders, pilgrims, travellers, settlements, and institutions.

In chapter 3, the Kêrala Varttamānam removes the Tuhfa's derogatory descriptions of the Portuguese and their tactics and manners. It follows the Tuhfa in the remaining parts, except in the last paragraph where the Tuhfa discusses the Portuguese battles in Jeddah. In chapter 4, the descriptions of the battle between Muslims and Portuguese at Pantalāyani Kollam and another fight between Muslims and Jews at Koṭuninallūr, both in 1524, have been removed. The last portion of this chapter, a brief account of a trade trip by some merchants in Malabar to Gujarat in 1530-1531 and consequent battles and events also has been removed. In Chapter 5, the section on the second Zamorin-Portuguese treaty is shortened significantly. The last part in this chapter, on the Portuguese battle in Diu, is also removed. The penultimate section on the Zamorin's fight with the chieftain of Câliyam is shortened in order to combine it with the descriptions of the Zamorin's fight and treaty with the king of Tānūr mentioned in chapter 6 of the Tuhfa. It also avoids other details from chapter 6. All other details of chapters 3 to 6 are the same. It skips chapters 7 to 10 of the Tuhfa entirely. It mentions the fifth Zamorin-Portuguese treaty of 1555 (chapter 11 of the Tuhfa) in one sentence, while again skipping most details of chapters 12 to 14 of the Tuhfa.

In the next brief section, the Kérala Varttamānam provides a quick run-through of some events in a chronological order. To give some examples, it mentions Kutți Pōkkar Marakkār's capture of Portuguese ships as an event that happened in $970 \mathrm{AH}$ (or 739 Kollam Era), whereas the Tuhfa mentions two such captures. One happened on Saturday, 8 Jamād al-Ākhir, $976 \mathrm{AH} / 1568 \mathrm{CE}$ and the other towards the end of Jamād al-Ākhir, $978 \mathrm{AH} / 1570 \mathrm{CE} .{ }^{11}$ But it does not provide the date 970 the Kérala Varttamānam mentions. The following description in the Kérala Varttamānam of the Zamorin's battle with Cochin in $974 \mathrm{AH} / 743$ Kollam Era and his subterfuge with the king of Tānūr to escape the Portuguese seizure are not mentioned in the Tuhfa. The following two incidents, the Zamorin's victory over the Portuguese at Cāliyam in $979 \mathrm{AH} /$ $1571 \mathrm{CE} / 747 \mathrm{KE}$ and the Zamorin-Portuguese peace treaty of $992 \mathrm{AH} / 1583 \mathrm{CE} / 760 \mathrm{KE}$ are mentioned in the Tuhfa in great detail, in chapters 13 and 14 respectively. The Kérala Varttamānam reduces those into each sentence. Following these two descriptions, it provides another incident as its last account: an event happened in $998 \mathrm{AH} / 766 \mathrm{KE}$ : "The Portuguese seized a vessel of the king at sea and consequently they again quarrelled." This incident is also not mentioned in the Tuhfa, which ends with a narrative in 1584.

The discrepancy in the year for Kuțti Pōkkar Marakkār and the two additional events unmentioned in the Tuhfa indicate that the Kerrala Varttamänam depended on an additional source to produce this information, unless its author witnessed the events himself or herself. It is possible that the author added these events based on firsthand information or translated, noted, or copied it down from a different informant or material. It is difficult to know the source of these details, especially the differences between the manuscripts of 
the Tuhfa are yet to be studied. Despite its wide circulation among historians both in the Arabic original and in translations, there is no critical edition.

There are a few trivial methodological changes too. While the Tuhfa sometimes speculates on the numbers of ships or victims of war, the Kérala Varttamānam always goes to the highest numbers provided in the Tuhfa. For example, on the number of Portuguese ships that came to the Malabar Coast in 1503, the Tuhfa gives different possibilities varying from twenty, twenty-one, and twenty-two to twenty-eight and eighteen. ${ }^{12}$ The Kérala Varttamānam mentions twenty-eight without any speculation. ${ }^{13}$ At another occasion, the numbers killed in the first encounter between the Portuguese and Calicut is sixty or seventy in the Tuhfa, whereas it is seventy in the Kerala Varttamānam. Similarly, in one of the first battles between Cochin and Calicut in the early sixteenth century, the number of Cochin royals killed is two or three in the Tuhfa, whereas it is undoubted three in the Kèrala Varttamānam.

The discrepancies in numbers and dates and the selection and deletion of particular portions are intentional choices by the translator. Such issues are noticeable once we read the text closely against the original, and this aspect does not nullify the foundational fact that the Kerrala Varttamannam is a translation of the Tuhfa to the extent that a rendering can reproduce an original text authentically in the sixteenth to eighteenth centuries. This text, whether in Wye's translation or in its Malayalam original, therefore cannot be taken as an exclusive and revelatory voice of the pagan king with "insights into the actions and attitudes of Malabar's political elite," as Prange argues. Nor is it a document belonging to the granthavari tradition that Kerala Brahmins followed to record events. It is only a rendering of the voice of the Tuhfa that Prange discredits because "the words and motives of the Hindu sovereign are once more attributed to him by others.",14 Instead of presenting the text as an exclusive Malayalam source on the Portuguese arrival, both the Tuhfa and Kérala Varttamānam should be understood as interconnected indigenous sources (without discriminating on the basis of the language) that have great potential to describe events in the voices of the local people.

Prange's argument that the Malayalam text is not a copy of Zayn al-Dīn's work should be reconsidered. His approach takes the ways in which certain Malayalam words are treated within the Arabic text and, with the help of an example, he argues that confusing a descriptive designator for a personal name "is easy enough to reconstruct under the assumption of a Malayalam-to-Arabic translation, whereas it becomes nonsensical in the reverse." 15 The example he uses is the term "Eliatha" (or Ilayatu) in the Wye translation for a minister of the Zamorin. He writes that this term is rendered as the name "al-Yadh" in the Arabic text. I argue that this is a misreading of the Arabic text and its Arabic-Malayalam context. Prange, as well as the English translator Nainar, misread and mistranslate the term as a personal name. ${ }^{16}$ In the British Library manuscript he cited, the term is written as اليذ without short vowel marks. ${ }^{17}$ Those who are familiar with only Arabic would read it as (al-yad), as Prange and Nainar have done. However, we are dealing with a Malayalam word in an Arabic text: It is a Malayalam term that should be vocalised as إلَََّْ (Ilayad), as it has been done in another British Library manuscript and a Royal Asiatic Society manuscript. ${ }^{18}$ The diacritical dot 
above "j" (d) in all these manuscripts should not be overlooked, for it indicates the Malayalam dental consonant $t a(())$, which in this context should be pronounced aspirated with more voice than the usual $t a{ }^{19}$ To indicate this aspirated spelling, the scribe or the author must have brought a hypercorrection to the Arabic letter ذ. It was a common practice for Malabar Muslims in general and for Zayn al-Dīn in particular to write Malayalam phrases or words in Arabic script, and had been since the sixteenth century, if not before. The whole Arabic-Malayalam literature is a product of this writing practice. Zayn al-Dīn has written many Malayalam words in the Arabic script elsewhere in the Tuhfa as well as in his other Arabic texts, in addition to transliterating several Malayalam names of places and people into Arabic script. ${ }^{20}$

Moreover, Illayatu in this context does not follow what Prange assumes is "a commonly used Malayalam word for 'younger one'; this minister was likely a junior relation of the Zamorin. ${ }^{21}$ In fact, it was a common title for the second minister of the Zamorins, similar to the way the title Zamorin (Malayal. Sāmūtiri) was borne by the incumbent ruler. ${ }^{22}$ Besides these, the text has many more Arabic terms which are uncommon in a pure Malayalam text, ranging from words such as tārīh (Arabic tārīkh: "date"; wrongly translated/transliterated by Wye as "Talika") repeated on almost every page to mausam (Arabic mawsim: "season"), kāti (Arabic qāḍi: "judge"), kissa (Arabic qișsa: story). These terms are seldom used in premodern Malayalam texts and thus indicate that this text depended on an Arabic source, or more precisely the Tuhfa of Zayn al-Dīn. This is further ensured by the plain mention of Hijri Era throughout the text along with the Kollam Era. A premodern Malayalam text, to my knowledge, would never include a Hijri Era in its chronology, and the fact that this text repeatedly cites both Kollam and Hijri eras, along with the aforesaid Arabic vocabularies, indicates a translation process that accommodates the norms and concerns of both the source and target languages.

\section{Translation Process}

The next question is who translated this text from Arabic to Malayalam. The source as such does not specify the translator or the process. Whoever he or she may be, the writer was either well versed in the Malayalam and Arabic languages in order to address both target and original languages, or she or he had immediate access to translator(s) who helped him or her with the Arabic or Malayalam text. The sentence at the end of the Kérala Varttamānam indicates this latter possibility, as it reads "kolikkotta kātiyārute kissāvil ninnu paraññu elutippatatre," that is, the text "has been written down on dictation from the kissa of Calicut's qāạī." The compound verbal form "parañ̃nu elutippatatre" literally means "had told to be written" or "written down while dictating." This indicates the mode and method of translation-cum-interpretation of the text. There may have been a Malayali Muslim scholar who read the Tuhfa in Arabic and summarised it in Malayalam for a Hindu scribe/scholar who noted it down with his or her own additions. The text has a good influence of Māppila Malayalam (or Arabi-Malayalam) in which Arabic is a predominant influence, and as a script-practice was widely written 
in the Arabic script up until the mid-twentieth century. Several words, phrases, or usages emerge from Māppila usages, such as tārīkh (for date/history) and mausam (season, monsoon in particular). The nature of sentence construction becomes clear once we compare it with the early Arabic-Malayalam texts such as the Muhy al-Dīn Māla, written in the early seventeenth century, and Kappappāttu and Nül Madh from the eighteenth century.

The addition of prayers in the Brahmanical (or Hindu) style at the beginning and end of the text (Hariḥ in the beginning; Srī gurubhyō namah subhastuh at the end) underscore the possibility that the Malayalam part was written by a Hindu. Although it is definitely possible, so far we do not have evidence from premodern Malabar to suggest that a Hindu scribe or scholar in the region mastered Arabic to the point of translating a historical text. The same goes the other way as well: even though it is possible, we do not yet have solid evidence to suggest that a Malayali Muslim would write prayers in Brahmanical style in his or her text with a high incidence of Sanskrit phrases. Furthermore, an interesting division in Kerala manuscript culture reaffirms this phenomenon: all Arabic manuscripts from the sixteenth to eighteenth century are in paper, whereas most Malayalam materials from the same period are in palm-leaf. This division in writing habits and uses of materials along linguistic and religious lines is yet to be studied thoroughly, but the larger known patterns suggest that the scribe/scholar for the Malayalam text came from a Hindu background and the oral translator had a Malayali Muslim background. The absence of Sanskrit terms and idioms besides the prayers and remarks at the opening and closing lines (the Malayalam literature in the sixteenth to eighteenth centuries is highly influenced by Sanskrit vocabulary) and the presence of several Arabic words throughout the text further strengthens this argument. This independent translation-cum-interpretation process is obvious in its bringing together of the Kollam Era with the Hijri Era. It does not replace the Islamic calendar, but rather synthesises it with the Kollam. In the same mode, John Wye also must have had a local interpreter to translate some nuanced words and usages. It is remarkable how accurately he translates some confusing Malayalam terms like varșam (usually used for year, but in the particular context of this text, for rain) and tippettu (royal death).

A further question arises: when was the Kérala Varttamānam written? There are two possibilities: either in the late sixteenth century or in the late eighteenth century. We mentioned above that the text at its final lines mentions briefly two incidents that happened in the late sixteenth century which are unmentioned in the Tuhfa: the Zamorin's battle with Cochin in $974 \mathrm{AH} / 743$ Kollam Era and his subterfuge with the king of Tānūr to escape the Portuguese seizure of a vessel of the Zamorin in $998 \mathrm{AH} / 766 \mathrm{KE}$, leading to further quarrels between both sides. I mentioned above that these additions indicate that the Kérala Varttamānam depended on an additional source for these two incidents. Possibly, the translator and/or the scribe witnessed these events and thought of including them. If this is the case, the text was written in the late sixteenth century. But if the colophon of the Kerala Varttamānam on its year of writing (1792) can be taken at its face value, it was produced only in 1792 as a free translation, possibly at the request of British officials such as John Wye who would eventually translate it into English. If 
this is the case, what is its source for the two incidents mentioned above? Possibilities include other local or Portuguese texts that record the events. ${ }^{23}$

\section{Implications of the Text}

The very existence of the Kerala Varttamanam and the fact that it is a rendering of an Arabic text makes it unique in premodern Malayalam literature in several respects. First of all, it is a complete text preserved in original Malayalam describing the Portuguese arrival in the Malabar Coast, probably the only one of its kind. Few of the premodern Malayalam literary texts available to us from the period during the Portuguese and Dutch presence between 1500 and 1800 discuss the European expansion or presence in detail. This silence is surprising in light of the Europeans' remarkable interventions in the region through centuries of conflict, commerce, conciliation, contribution, and disruption. Most of the Malayalam texts available to us from the period belong to the genres of Hindu bhakti spirituality, epic, humour, and hagiography. A few other exceptions to this pattern would include the Patappāttu (War Song), on the Dutch conquest of Cochin in the 1660s, the Kéralōtpatti and Kéralanātakam on the mythical origin of the province with a brief section on the Portuguese in the former, and Māmāinkam Kilippāttu , on one particular Zamorin. ${ }^{24}$ All these texts were written in the seventeenth century. The only Malayalam materials on the Portuguese available from the sixteenth century are a few fragmentary records from the Zamorins' palace records, commonly known as Kolikkottan Granthavari. ${ }^{25}$ All these aspects make the Kérala Varttamānam even more special as it is written exclusively and elaborately on the Portuguese encounters with the Zamorins in the sixteenth century.

Secondly, this absence of Malayalam texts on the theme is even more surprising once we compare it with the survival and presence of at least five Arabic texts written in Malabar in the sixteenth century on the Portuguese alone. Such Arabic texts, with strong jihadi contents, produced from the early decades of the sixteenth century till its last decades, are splendid evidences of the local responses to the Portuguese incursions. The most renowned among those is the Tuhfa, but there are four more texts. ${ }^{26}$ This impressive number of Arabic texts vis-à-vis the silence of the Malayalam literary sphere would have been an enigmatic phenomenon, were it not for the Kérala Varttamānam.

Thirdly, between the sixteenth and eighteenth centuries we have several religious, metaphysical, hagiographical, epic, and/or humorous works in both Malayalam and Arabic, produced from the same Malabar microregions, such as Ponnāni. In fact, Tuñchattu Eluttacchan, the so-called founder of modern Malayalam literature, is said to have born and brought up in the vicinity of Ponnāni and produced his epics Ádhyātma Rāmāyanam and Mahābhāratam Kilippāttu in this area. ${ }^{27}$ The author of the Tuhfa, Zayn al-Dīn, was brought up in the same locality. He studied and taught at the Ponnāni Mosque-College for several years, just like his father, uncle, and grandfather, who all were renowned scholars of Islam and produced several texts in Arabic which continue to be in circulation across the Indian Ocean world and beyond. ${ }^{28}$ His grandfather Zayn al-Dīn Sr. (d. 1522) wrote the first known anti-Portuguese treatise in Arabic from 
Malabar, titled Tahrị̣̂ ahl al-īmān 'alā jihād 'abadat șulbān (Inciting believers to fight against cross-worshippers) in the early decades of the sixteenth century when the conflicts between the Portuguese and the Zamorins of Calicut were in initial stage. ${ }^{29}$ Despite of their geographical, chronological, and cultural proximities, we do not come across any evidence of literary interactions between the Malayalam literary sphere and the Arabic literary sphere. We do not see them even acknowledging each other's presence in their writings, let alone citing each other's works, following genres, or discussing similar themes. While one group wrote in Malayalam, creating new trends in the region or following the larger Sanskrit literary patterns in discussing metaphysical, religious, and epic themes, morals, and teachings, the other group produced works in Arabic following the textual longue durée of Islamic literary productions in law, mysticism, ethics, and hagiographies. ${ }^{30}$ All the texts available to us from either side are limited to their own long textual, intellectual, and religious genealogies, and are hardly in conversation with one another. In the known palm-leaf documents in particular we rarely come across any references to the Arabic texts. This disconnectedness between the inhabitants of the same Indian Ocean town is intriguing given the long span of at least three centuries. In this general pattern too, the Kérala Varttamānam stands in sharp contrast by presenting a fascinating story of larger cross-cultural and cross-language exchanges between the two spheres.

Copying the Kérala Varttamānam was finished on 25 Karkațakam 967 KE (1792 CE). This date is interesting as it is the same year in which Tipu Sultan of Mysore (r. 17821799) handed over the rule of Malabar to the English East India Company. The arrival of the English and their takeover of the region must have stirred the historical memory of the copyist (and the translator if it was translated in this period), those who funded them, and their potential audience about the earlier advent of another European empire that created significant ruptures in the social and political scenarios of the region, as narrated in the Kérala Varttamānam. Its historicised memory eventually became enacted history in the following decades when the local communities of Malabar resiliently resisted English colonisation through a series of battles very similar to their fights against the Portuguese. In that respect, the text became an epilogue to (and a memory of) the Portuguese arrival, but a prologue to (and a prophecy of) the English arrival.

Within a year of its completion, in 1793, a copy was in the hands of English officials. Two Indian scholars note that the British acquired the manuscript from Valiya Qâdī of Calicut, but they do not give any references on how this happened. ${ }^{31}$ If true this is even more interesting, in the sense that it would tell us about the potential possessors of the original manuscript, its original author, their group association, and so on. However, this is contradicted by the colophon at the end of the Wye's translation, which provides firsthand information that the document was "presented" to the Englishman by the Venkatycotta Raja of the Zamorin family. John Wye translated it into English by 1800 , and at least two copies survived. ${ }^{32}$ The form and structure, and additional notes in the margins of these two manuscripts, indicate that his translation was read and circulated by several hands.

The Kérala Varttamānam is not an unknown text to historians in Kerala, although they have not used it much to study the Portuguese encounters with Malabar or other historical, 
cultural, and literary aspects. K. K. N Kurup and K. Vijaya Kumar transcribed and published it in 1995 (reprinted in 2012) with a short introduction. ${ }^{33}$ They have kept the language of the manuscript intact, but they have changed all the Hijri and Kollam years into Common Era years. In their brief introduction they mention that the document was collected by the British from the Valiya Qādī of Calicut, but they do not provide any reference and it is questionable on the basis of the Wye colophon. There are a few errors too in their transcription.

Because we have John Wye's translated text from 1800 and Sebastian Prange has published it recently, there is no point in retranslating the entire text once again. Here I shall direct the readers' attention to a few important omissions in Wye's translation along with a few missing or mistaken translations in the Wye manuscripts (and consequently Prange's transcription), as well as the transcription into Malayalam by Kurup and Kumar.

In Wye's translation, the missing sentences are (a) the first sentence: Harih. Kéralattile varttamānañial iniyum parayunnu which means, "God. Telling again the narratives of Kerala." "34 The title Kérala Varttamānam must have emerged from this first sentence, for nowhere in the text or document there is any indication of a title. In the manuscript, the title is written by a different hand; (b) the last two sentences in Sanskrit and Malayalam we transliterated and translated above, on the completion and source of the text. To repeat it with its translation: "Śrī gurubhyō namah subhastuh $\bar{l}$ varttamānam kollam 25 Karkațakam 967nu kolikkoțta kātiyāruțe kissāvil ninnu paraññu elutippatatre” which means, "Blessings and salutations to the guru, this is the good end. This account (varttamānam) has been written down on dictation from the kissa of Calicut's qâdī on

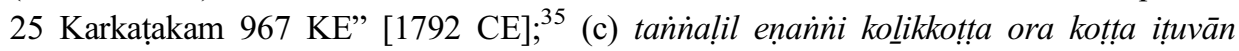
samatikkukayum ceytu, or "they reconciled with each other and agreed to establish a fort in Calicut." 36 This is in relation to the treaties in the year 1514-15. (d) a kottappani tīrunnatinte munpe à kollattil tanne tāmūtiri rājāva tīppețkayum ceytu, or "the king Zamorin died that year itself before the construction of the fort was over." ${ }^{37}$ The fort referred to here is the Câliyam Fort. All these are full sentences, but there are also a few words missing in other spots, such as "and the Mappilas" in a sentence about the fort. The Arabic names for people or months have been translated so wrongly that it would seem to no one that these are Arabic months. This comes along with the repeated transliteration of târikkh (the date) as an alien term Talika.

In Kurup and Kumar's transcription, the major problem is that they have converted all the dates into Common Era years, and some of these converted years are not accurate. Wye's translation has kept both original dates (the Kollam and Hijri eras), but has not converted them. Besides this, one important mistake in Kurup and Kumar's transcription is that the number of Nair militia who joined the Zamorin's attack against Cochin in 1504 is nürāyiram $(100,000)$, which has been transcribed as ārāyiram $(6,000)$. Wye has translated it correctly, and the Tuhfa also provides the number as 100,000. 


\section{Does the Pagan King Reply?}

If we now accept that the Kerala Varttamannam is not the exclusive voice of the Indian king but a translation of the Arabic text, is there any other way to hear his voice in his own language with regard to the Portuguese arrival? Yes, definitely there is. This manuscript indicates the presence of a larger literary tradition that must have produced a significant amount of historical materials, many of which must have been lost; yet not entirely. There are several palm-leaf documents preserved across Kerala, some of which have been digitised and preserved through such initiatives as the British Library's Endangered Archives Programme. ${ }^{38}$ For the history of the Zamorins in particular, the records from their Ponnāni palace have currently been preserved at the Vallattō! Vidyāpîtham and other private and informal collections. Several Indian historians have studied and published them in the last two decades. ${ }^{39}$ These documents belong to a period from the sixteenth to the nineteenth centuries and record various cultural, economic, political, religious, and legal events in the dominion of the Zamorins. Most of those do not engage with the Portuguese incursions directly, for they had much bigger concerns of their own, yet they do provide intermittent references to the Europeans in general or the Portuguese in particular, as we can see in the twelfth and fourteenth volumes of the Kolikkōtan Granthavari. ${ }^{40}$

The most renowned Malayalam document on the history of Kerala, the Kéralolpatti, does provide a short account on the Portuguese arrival in the region. Historians have questioned the authenticity of this text, for it delivers several anachronistic, mythical, and ahistorical descriptions on the early history of the region. Even so, they have argued that it does contain some historical grains of the region's early medieval social and political formations and transformations. They generally agree that it must have been written in the sixteenth to eighteenth centuries, if not before. ${ }^{41}$ For the present focus, its brief account on the Portuguese does not contradict any known historical facts or events and therefore can be considered of historical value for the period. Under a subsection titled "Portuguese arrival and the relationship with the Kurumpiyātiri," it says: "As time passes, when the Portuguese landed at Calicut, established a fort, conducted commerce (a round-hatted captain from Pandy (Pānțtiparadéśi) named Arayil Kuriyan fought against [the Portuguese]), conquered Calicut, ruined some of its shoreline. At a time when everyone apart from Tinayanceri Ilayatu had gone south for a battle, he [the Portuguese] sent a letter to the Kurumpiyātiri Svarūpam, fetched them (by the grace of Vẹttakkorumakan), ousted him through battle and conquered the fort. It is heard that at that time they got a lot of wealth, jewels, commodities, and cannons." 42

In the following lines, the Kéralōlpatti describes the grace of the family deity Vẹttakkorumakan that protected the land during the Portuguese assaults and provides further details on the wars and booties. It moves on to enumerate the implications of these battles and booty on the future trajectories of local chieftaincies. This short description provides a Brahmanical/Hindu perspective on the Portuguese-Zamorin battles along with a stint on the Muslim involvement. Its use of the term Pāṇtipparadéśi (a foreigner from Pāṇtii) to denote possibly the Kuññāli Marakkārs might be an indication of the 
origin of the Marakkār family from the Coromandel Coast. Pānți is generally a Malayalam term used for Tamils with indications to the Pandya genealogies, while paradēsi indicates foreigners in general or the foreign Muslims in particular, as Duarte Barbosa differentiates them from the local Mappila Muslims. ${ }^{43}$

With regard to the Portuguese happenstances however, another elaborate and important Malayalam text is the Kérala-palama, which describes the first three decades of Portuguese-Calicut encounters. It is a detailed account that "reads like a diary giving day-to-day account of what happened" and "judged from its language and general tone ... [it] represents the Portuguese version of events." $" 44$ The text was first published by the German philologist Hermann Gundert at the Basel Mission Press in 1868 and it was recently translated into English by T. Madhava Menon and published by the International School of Dravidian Linguistics. ${ }^{45}$ It is written as a continuation to the Kéralolpatti that had only made passing reference to the arrival of the Portuguese. The title pages of the first printed edition of the Kérala-palama claim to describe events from 1498 until 1631, but this is incorrect. It talks mainly about a period until 1530. The whole monograph is centred on this, even though it does briefly mention in the last lines the Dutch (Hōllantar) victory against the Portuguese in Cochin in $1663 .^{46}$

This text's focus on the early sixteenth century is intriguing compared with the fact that the Tuhfa (and hence the Kérala Varttamānam) also focuses on events until 1530-31. All these three texts describe the events after this period more haphazardly and incoherently. Although the Kérala-palama and the Tuhfa (and hence the Kérala Varttamānam) have completely different narrative styles and contents, they all unite in ending their major discussions at the same year in a chronological bracket. While the emphasis of the Tuhfa and the Kerrala Varttamānam makes sense with the latter being an independent and free translation of the former, the same choice in the Kérala-palama is striking and needs further exploration into why these texts together take this year as a primary endpoint. For the moment it suffices to say that the first three decades seem to be a matter of great historical and historiographical importance for the Malayalam and Arabic audience, authors, scribes, and translators.

In the Kérala-palama, Gundert has brought together several sources in Malayalam and other Indian and European languages. He prioritises the Portuguese narratives and their legacies with accurate names and descriptions of their officials, admirals, and kings while paying similar attention to their Malabari counterparts. This should be read along with Chelnat Achyuta Menon's statement that the text is a Portuguese version of the events while the Kérala Varttamannam is a Muslim version of the same. ${ }^{47}$ Notwithstanding these aspects, the Kérala-palama definitely provides a Malayali/ Calicut perspective, for it uses a lot of peculiar contexts and names which are otherwise not known in other sources and gives versions of encounters, narratives, and events that are not in the best-known Portuguese, Dutch, and French accounts. ${ }^{48}$ Most of its information must have been noted down by someone who had witnessed the events in person, unless they are fanciful imaginings and additions by Gundert himself. Unfortunately the text does not provide an indication of its sources. However, two correspondences from the Zamorins' palace records demonstrate that Gundert had access to materials kept at 
the royal library, and a handsome portion of Kérala-palama's accounts on Calicut's role must have come from those sources. ${ }^{49}$ A closer study of the text would reveal its historical, historiographical, literary, and linguistic characteristics and contributions.

\section{Conclusion}

The Kérala Varttamānam is definitely a translation of the Arabic text Tuhfat al-mujāhidīn. It is not an original Malayalam text belonging to the granthavari tradition as Prange has argued. Therefore, it does not afford "a distant echo of the pagan king speaking at last." Through the intermediation of an Arabic-literate Muslim scholar and a Malayalam-literate Hindu scribe, the Tuhfa was rendered as the Kérala Varttamannam in the sixteenth, or most probably in the eighteenth, century. It is intriguing to note that the Wye translation has intentionally or inadvertently removed the source of its Malayalam original.

The very existence of this translation in the eighteenth century, if not before, points towards the cross-cultural and cross-linguistic interactions between the Arabic and Malayalam spheres of premodern Malabar. The text demonstrates one of the first instances in which Malayalam literature addresses such a secular and historical theme as the arrival of the Portuguese. One precedent, if not successor, to this genre in Malayalam literature would be the seventeenth-century war-song on the Portuguese-Dutch battle in the $1660 \mathrm{~s}$ in and around Cochin with the leading participation of the rulers of Calicut and Cochin. ${ }^{50}$

Particularly on the Portuguese arrival and its immediate aftermath, we have to await further input to learn what the Zamorin rulers of Calicut and their subordinates said, thought, and did through and beyond their palace records. However, while we search for such "indigenous" voices or sources on the Portuguese arrival, we should not discredit the indigeneity of such Arabic texts as the Tuhfat al-mujähidin, which was written by a Muslim scholar who was born and brought up in a family that had long settled in the Malabar Coast. If we discredit their indigeneity for the fact that it was written in Arabic or by a Muslim, we inadvertently add to the charged Indian right-wing discourses that portray Muslims as foreigners and invaders. In addition, we also should not succumb to the opposite notion that the Tuhfa is the only indigenous text available from the region for the fact that Kérala Varttamānam and the Wye manuscript are its translations. Works such as the Malayalam texts Kéralōlpatti and Kérala-palama can stand as clear voices from Malabar on the Portuguese arrival and consequent episodes. Further investigations into local sources in Malayalam, Sanskrit, and other Indic languages that are now being uncovered and digitised will likely shed more light there. This approach is more productive than usual excuses about the absence of sources.

\section{Acknowledgements}

I would like to thank Abhishek Avtans and Gijs Kruijtzer (Leiden University, the Netherlands), V.V. Haridas (Calicut University, India), Abbas Panakkal (Griffith 
University, Australia), Abhilash Malayil (Hebrew University of Jerusalem, Israel), and two anonymous peer-reviewers for their inputs on the earlier drafts of this article and/or their help with the source materials. I am also thankful to Daniel Lowe of the British Library and Edward Weech of the Royal Asiatic Society for facilitating consultation of the manuscripts despite of my untimely requests. I wrote this paper while working in the project "Understanding Sharia: Past Perfect, Imperfect Present", funded by the Humanities in the European Research Area (HERA). I am also grateful to the project team.

\section{Bibliography}

\section{Unpublished Primary Sources}

British Library, London India Office Records (IOR)

Ms. Malayalam $11^{*}$, Kerala Varttamānam

Ms. Islamic 2799: Shaykh Zayn al-Dīn, Tuhfat al-mujāhidīn.

Ms. Islamic 2807d and Or. 1738: Anonymous, Qișșat Shakarwatī Farmāẹ

Ms. Islamic 2807e: Zayn al-Dīn al-Malaybārī, "Tuḥfat al-mujāhidīn fì Ba'ḍi Akhbār al-Burtughāliyyīn".

Ms. Islamic 2807f: Muḥammad al-Kālikūtī, "al-Fatḥ al-mubīn"

Add Ms. 22375: Shaykh Zayn al-Dīn, Tuhfat al-mujāhidīn.

MSS. Eur.K.194 and Eur.K.195: John Wye, "Translation of a History of the Portuguese landing in India, written on the leaves of the Brab tree (called Ola) in the Malabar language".

Eberhard Karls Tubingen University Library,

Hermann Gundert Collection,

MaI. 864-5: Tuñcattu Rāmānujan Elıttacchan, Kēralanātakam.

MaI. 849: Anonymous, Keralolpattimūlam.

Royal Asiatic Society, London

Arabic 28. Zayn al-Dīn al-Malaybārī, Tuhfat al-mujāhidīn fì ba 'ḍ akhbār al-Burtughālīỳ̄n

Vallathol Vidyapeetham Library, Kerala

Kolikkōtan Granthavari. Palm-leaf Manuscripts: vols. 12 and 14.

\section{Published Primary Sources}

Albuquerque, Affonso de. Cartas de Affonso de Albuquerque seguidas de documentos que as elucidam. Lisbon: Typographia da Academia Real das Sciencias, 1884-1935.

Anonymous. Calcoen: A Dutch Narrative of the Second Voyage of Vasco Da Gama to Calicut Printed at Antwerp circa 1504. Introduction and translation by J. Ph. Berjeau. London: Basil Montagu Pickering, 1874.

Anonymous. A Journal of the First Voyage of Vasco da Gama, 1497-1499. Edited by E. G. Ravenstein. London: Haklyut Society, 1888.

Anonymous. Kẽrala-Parama or History of Malabar from A. D. 1498-1631 [sic]. Mangalore: Basel Mission Press, 1868.

- Kerala pazhama: Antiquity of Kerala. Translated by T. Madhava Menon. Thiruvananthapuram: International School of Dravidian Linguistics, 2003.

Anonymous. Kēralōlpatti. Mangalore: Basel Mission Press, 1868.

- Kéralōlpatti by Gundert. Translated by T. Madhava Menon. Thiruvananthapuram: International School of Dravidian Linguistics, 2003.

Anonymous. Patappāttu. Edited with an introduction by S. Paramesvara Aiyar. Travancore: Authority of the Government, 1924. 
Barbosa, Duarte. The Book of Duarte Barbosa: An Account of the Countries Bordering on the Indian Ocean and Their Inhabitants. Farnham: Ashgate, 2010.

Barros, Joao de. Da Asia: Dos Feitos, Que os Portuguezes Fizeram no Descubrimento, e Conquista dos Mares, e Terras do Oriente. Lisbon: Regia Officina Typografica, 1777.

Castanheda, Fernão Lopes de. História do descobrimento e conquista da India pelos Portugueses. Coimbra: Barreyra \& Aluarez, 1551.

Kurup, K. K. N., ed. Kavalappara Papers. Calicut: University of Calicut, 1987.

Kurup, K. K. N., and K. Vijayakumar. "Kērala Varttamānam: Oru Vāmoli Caritra Rēkha." In Tuhfat al-Mujāhidīn by Shaykh Zayn al-Dīn Makhdūm. Translated into Malayalam by C. Hamsa. Calicut: Al-Huda Book Stall, 2012 [first published in 1995].

Makhdoom I, Zainuddin [Zayn al-Dīn Sr.]. Tahrị̀ Ahl al-İmān 'Alā Jihād 'Abadat Sulbān. Edited and translated by K. M. Muhammad. Calicut: Other Books, 2013.

al-Malaybārī, Zayn al-Dīn. Ajwibat al-'ajība 'an al-as'ilat al-gharība. Edited by 'Abd al-Nașīr Aḥmad al-Shāfi '̄i al-Malaybārī. Kuwait: Dār al-Ḍiyā', 2012.

al-Malaybārī, Zayn al-Dīn. Tohfut-ul-mujahideen: An Historical Work in the Arabic Language. Translated by M. J. Rowlandson. London: Oriental Translation Fund of Great Britain and Ireland, 1833.

al-Malaybārī, Zayn al-Dīn. Tuhfat al-mujāhidīn fī ba'ḍ akhbār al-Burtughālìỳinn. Tripoli: Kullīyat al-Da wat al-Islāmīyya, 1987.

al-Malaybārī, Zayn al-Dīn. Tuhfat al-Mujāhidīn: A Historical Epic of the Sixteenth Century. Translated by S. Muhammad Husayn Nainar. Kuala Lumpur: Islamic Book Trust and Calicut: Other Books, 2005.

Nampoothiry, N. M., ed. Māmānikam Rēkhakaḷ. Sukapuram: Vallathol Vidyapeetham, 2005.

—_ ed. Sāmūtiricaritrattile Kānāppurangal. Sukapuram: Vallathol Vidyapeetham, 1987.

—

Narayanan, M. G. S., ed. Vanjeri Grandhavari. Calicut: Dept. of History, University of Calicut, 1987.

Pires, Tome. The Suma Oriental of Tome Pires. Edited and translated by A. N. Cortesão. London: Hakluyt, 1944.

Rajendu, S., ed. Arangode Swaroopam Granthavari, Tirumanamkunnu Granthavari. Sukapuram: Vallathol Vidyapeetham, 2016.

Varier, M. R. Raghava, ed. Kēralōlpatti Granthavari. Kottayam: Sahithya Pravarthaka Co-Operative Society, 2013.

—- ed. Sthānārōhaṇam: Cațan்inkal. Sukapuram: Vallathol Vidyapeetham, 2004.

Vijayakumar, K. "Kerala Varthamanam or the News of Kerala." In India's Naval Traditions: The Role of Kunhali Marakkars, K. K. N. Kurup, 96-103. New Delhi: Northern Book Centre, 1997.

\section{Secondary Sources}

Amer, Ayal. "The Rise of Jihādic Sentiments and the Writing of History in Sixteenth-Century Kerala," The Indian Economic \& Social History Review 53:3 (2016): 297-319.

Fayḍ̄i, M. A. Bīrānkutți. Shaykh Zayn al-Dīn Makhdūmum Ponnāni Jumu 'attu Pallịyum. Ponnāni: Ponnāni Valiya Jumu 'attu Paḷi Paripālana Committee, 1994.

Friedmann, Yohanan. "Qișșat Shakarwatī Farmāḍ: A Tradition Concerning the Introduction of Islam to Malabar." Israel Oriental Studies 5 (1975): 233-45.

Gundert, Hermann. A Malayalam and English Dictionary. Mangalore: Basel Mission Book \& Tract Depository, 1872.

Haridas, V. V. Zamorins and the Political Culture of Medieval Kerala. Hyderabad: Orient Black Swan, 2016.

Kareem, K. K. M. Abdul, and C. N. Ahmad Moulavi. Mahattāya Māppila Sāhitya Pāranparyam. Kolikkōtuu: Published by the authors, 1978. 
Khan, M. A. Muid. "Indo-Portuguese Struggle for Maritime Supremacy (as Gleaned from an Unpublished Arabic Urjuza: Fathul Mubiyn)." In Studies in the Foreign Relations of India (from Earliest Times to 1947): Prof. H. K. Sherwani Felicitation Volume, edited by P. M. Joshi and M. A. Nayeem. Hyderabad: State Archives, Government of Andhra Pradesh, 1975.

Kooria, Mahmood. "Patappātțu, a Malayalam War-Song on the Portuguese-Dutch Battle in Cochin." In Malabar in the Indian Ocean: Cosmopolitanism in a Maritime Historical Region, edited by Mahmood Kooria and Michael Pearson. New Delhi: Oxford University Press, 2018.

_ . "Circuitous Imagination of Kingdoms in Sixteenth Century Malabar." Journal of Indian Ocean World Studies 1:1 (2017): 89-109.

Kugle, Scott, and Roxani Eleni Margariti. "Narrating Community: The Qiș̣̦at Shakarwatī Farmāọ̣ and Accounts of Origin in Kerala and Around the Indian Ocean." Journal of the Economic and Social History of the Orient 60:4 (2017): 337-80.

Mathew, K. S. Portuguese Trade with India in the Sixteenth Century. New Delhi: Manohar, 1983.

Menon, Chelnat Achyuta. Catalogue of the Malayalam Manuscripts in the India Office Library. London: Oxford University Press, 1954.

- Ezuttaccan and His Age. Thiruvananthapuram: International School of Dravidian Linguistics, 2017.

Muhammad, K. M. Arabi Sāhityattinu Kēraḷattinte Saṃbhāvana. Tirūraṅnāți: Ashrafi Book Centre, 2012.

Muralidharan, Meera G. Construction and Reconstruction of Authority in Keralolpatti: A Re-examination of a Contested Chronicle from Kerala. MA thesis, Leiden University, 2015.

Pearson, Michael. The Portuguese in India. Cambridge: Cambridge University Press, 2006.

Prange, Sebastian. "The Pagan King Replies: An Indian Perspective on the Portuguese Arrival in India." Itinerario 41:1 (2017): 151-73.

Raṇțattāṇi, Husain. Makhdūmuṃ Ponnāniyum. Ponnāni: Jumu attu Pạ̣li Paripālana Committee, 2010.

Subrahmanyam, Sanjay. The Career and Legend of Vasco da Gama. Cambridge: Cambridge University Press, 1998.

- The Political Economy of Commerce: Southern India, 1500-1650. New York: Cambridge University Press, 1990.

Veluthat, Kesavan. The Early Medieval in South India. New Delhi: Oxford University Press, 2012. Vilayatullah, A. I. "A Biography of the Author." In Tuhfat al-Mujāhidin: A Historical Epic of the Sixteenth Century, translated by S. Muhammad Husayn Nainar. Kuala Lumpur: Islamic Book Trust, and Calicut: Other Books, 2006.

\section{Notes}

* Mahmood Kooria is affiliated with Leiden University, the Netherlands, and Ashoka University, India. Currently he is working on a research project funded by the Netherlands Organisation for Scientific Research (NWO) on the historical and legal traditions of matriarchal Muslims in the Indian Ocean littoral. Earlier, he was a research fellow at the Social Science Research Council (SSRC), New York; Dutch Institute in Morocco (NIMAR), Rabat; International Institute for Asian Studies (IIAS) and the African Studies Centre (ASC), Leiden.
1 Prange, "The Pagan King Replies."

2 Menon, Catalogue of the Malayalam Manuscripts, 10. The asterisk (*) above the call number 11 is important as there is another Malayalam manuscript with the same call number without asterisk.

3 Prange, "The Pagan King Replies," 162.

4 For example, see Muhammad, Arabi Sāhityattinu, 71-2, 75, 89, 91, 104, 107, 109; Kareem and Moulavi, Mahattāya Māppila Sāhitya Pāranparyam, passim. Both these Malayhalam texts provide a survey of the works produced by the Malabari Muslims. 
5 For the text, British Library, IO, MS. Islamic 2807d, fols. 81b-104b; and Or. 1738; cf. Kugle and Margariti, "Narrating Community," 337-80.

6 The term kissa became popular only recently among Malayalam-speakers irrespective of religious connotations. The widely regarded Malayalam dictionary, Gundert, A Malayalam and English Dictionary, does not include this word despite its mentioning many other Malayalam words derived from Arabic.

7 "Kerala Varttamānam," fol. 3r-4r [curator's numbering: 27r-26r]. The curator/ collector who numbered the manuscript pages has confused the order by numbering the folios reversely with first numbers for last folios and vice versa, and misplaced the recto and verso more than once. He or she has done it despite the manuscript providing clear and correct folio numbers, albeit in Malayalam numerals. Compare this translation with the one by K. Vijayakumar, "Kerala Varthamanam," 97. His translation is rather loose: he misses the number five thousand.

8 British Library, IOR, MS. Eur. K.195, Wye, "Translation of a History of the Portuguese Landing," fol. 22r.

9 "Kerala Varttamānam," fol. $15 \mathrm{r}-16 \mathrm{v}$ [14v-13v]; cf. Wye, "Translation," fol. 30r; Vijayakumar, "Kerala Varthamanam," 99-100.

10 Friedmann, "Qiṣṣat Shakarwatī Farmāḍ," 233-45.

11 British Library, IO, MS. Islamic 2807e: Zayn al-Dīn al-Malaybārī, "Tuhfat al-mujāhidīn fī Ba đ̣̣i Akhbār al-Burtugāaliyȳ̄n”, fols. 145v-146r; British Library, Add MS 22375: Shaykh Zayn al-Dīn, Tuhfat al-mujāhidīn, fols. 23v-24r; British Library, IO, MS. Islamic 2799: Shaykh Zayn al-Dīn, Tuhfat al-mujāhidīn, fol. 30r-31r; Royal Asiatic Society, Arabic 28, Zayn al-Dīn al-Malaybārī, Tuhfat al-mujāhidīn fì ba'd akhbār al-Burtukālìyìn, fols. 71-2.

12 British Library, IO, MS. Islamic 2807e, fol. 129r; British Library, Add MS 22375, fol. 11r; British Library, IO, MS. Islamic 2799, fol. 11v; Royal Asiatic
Society, Arabic 28, fol. 37. Although the last number is eighteen in three manuscripts at the British Library (Islamic 2807e; Islamic 2799; Add MS 22375), it most likely is a scribal error of the first copyist for the logical progression must have been to twenty-eight. The manuscript at the Royal Asiatic Society provides it twenty-eight, not eighteen.

13 British Library, OMS/MSS Malayalam $11 *$, "Kerala Varttamānam," fol. 21v [8v]. In the Wye manuscript, ms. 1, it is mentioned as twenty ships while in ms. 2 it is twenty-eight ships. I do not know how this confusion came about.

14 Prange, "The Pagan King Replies," 153.

15 Prange, "The Pagan King Replies," 161

16 Prange has given the citation to the original British Library manuscript; for this mistranslation, see al-Malaybārī, Tuhfat al-mujāhidīn: A Historical Epic, 64. Rowlandson confuses the whole term and translates it as "Baleez", see al-Malaybārī, Tohfut-ul-mujahideen, 121.

17 British Library, IO, MS. Islamic 2807e, fol. 136 (line 4).

18 British Library, Add MS 22375, fol. 16v (line 15: last line); Royal Asiatic Society, Arabic 28 (line 10). However, British Library, IO, MS. Islamic 2799, fol. 19v (line 9) does not vocalise the word nor puts a dot on the letter. This is probably because it is written in Nasta liq by an uninformed scribe.

19 I am thankful to Abhishek Avtans for this insight into the common Dravidian writing and transliteration practices.

20 Another good example is his uses of the terms "nāyam," "bashanam," "bāna," "moli colliyan," "bashanam colliyan," etc. in al-Malaybārī, Ajwibat al- 'aj̄̄ba, 178-81.

21 Prange, "The Pagan King Replies," 161.

22 On these names, see Anonymous, Kéralōlpatti, 94-95. He was called Tinayañcēri Iḷayatu. The first minister was Mānnātt Accan, the third one was Dharmagunattu Panikkar, and the fourth one was Pāranampi. For more details on their names and functions, see Haridas, Zamorins, 23-8. 
23 For potential local sources, see the discussion below. For possible Portuguese sources, see Mathew, Portuguese Trade; Subrahmanyam, Political Economy of Commerce, 252-342; Subrahmanyam, Career and Legend of Vasco da Gama; Pearson, The Portuguese in India.

24 Anonymous, Patappāttu; for the translation of its first three parts, see Kooria, "Pațappāttu, a Malayalam War-Song," 141-71; Anonymous, Kéralōtpatti; Tuñcattu Rāmānujan, Kēraḷanătakam.

25 For example, see Kolikkōtan Granthavari, vols. 12 and 14.

26 For two recent contrasting studies on these texts, see Amer, "The Rise of Jihādic Sentiments"; Kooria, "An Abode of Islam with a Hindu King".

27 On his life and contributions, see Menon, Ezuttaccan and His Age.

28 For an overview of his life and contributions, Fayḍ̂̄, Shaykh Zayn al-Dīn; Raṇtattāni, Makhdūmum Ponnāniyum, 120-5; Vilayatullah, "A Biography of the Author."

29 Makhdoom I [Zayn al-Dīn Sr.]. Tahrị̣ Ahl al-īmān 'Alā Jihād 'Abadat șulbān.

30 An exception to this could be the Arabic-Malayalam literature with two texts available from the early seventeenth century and three more from the eighteenth century, but nothing from the sixteenth century. All these were produced by Muslim scholars who were well versed in the local language (Arabic-Malayalam was primarily used by the Muslims for Muslims until Christian missionaries started to publish texts in this medium in order to attract Malabari Muslims). Even so, nothing of this sort is known from the Hindu scholars to identify a literature in the reversed hyphenation, i.e. Malayalam-Arabic. If there was anything of that sort, the Kérala Varttamānam would have been the first in that genre.

31 Kurup and Vijayakumar, "Kèraḷa Varttamānam," 163.
32 British Library, India Office Records, MSS. Eur. K.194 and MSS. Eur. K.195.

33 Kurup and Vijayakumar, "Kēraḷa Varttamānam," 163-73.

34 "Kerala Varttamānam," fol. 29v [1r].

35 "Kerala Varttamānam," fol. 1r-v [28r-v].

36 "Kerala Varttamānam," fol. 14r [15r].

37 "Kerala Varttamānam," fol. 4r [25r].

38 For example, see British Library, Endangered Archives Programme EAP208, 584, 729 and 1039.

39 Prange is mistaken when he says that these are not used by historians. Some of the important studies or source publications based on such collections are Haridas, Zamorins; Varier, Sthānārōhanam; Rajendu, Arangode Swaroopam Granthavari; Nampoothiry, Māmāinkam Rēkhakal; Nampoothiry, Sāmūtiricaritrattile Kānāppurangal; Varier, Keralolpatti Grandhavari; Kurup, Kavalappara Papers; Nampoothiry, Vellayute Caritram; Narayanan, Vanjeri Grandhavari.

40 Kolikkōtan Granthavari, vol. 12, ōla 26; ibid., vol. 14, ōla 26.

41 Veluthat, The Early Medieval in South India; Muralidharan, Construction and Reconstruction of Authority.

42 Anonymous, Kēralōlpatti, 95-6.

43 Barbosa, The Book of Duarte Barbosa.

44 Menon, Catalogue of the Malayalam Manuscripts, 10.

45 Anonymous, Kérala-Parama.

46 Anonymous, Kérala-Parama, 194-5.

47 Menon, Catalogue of the Malayalam Manuscripts, 10.

48 For example, see Anonymous, A Journal; Anonymous, Calcoen; Barbosa, The Book of Duarte Barbosa; Pires, The Suma Oriental; Castanheda, História; Albuquerque, Cartas; Barros, Da Asia.

49 For a transcription of these two correspondences between the then Zamorin and the British district collector of Calicut, H. V. Conolly, who facilitated Gundert's access to the royal collection, see Nampoothiry, Sāmūtiricaritrattile, 301-2.

50 Anonymous, Pațappāttu. 